\title{
薬の経管投与に関する現状と問題点の検討
}

\author{
䇾原豪人 ${ }^{* 1}$ ，塩塚昭一 ${ }^{1}$ ，今村 健 $^{1}$ ，池内忠宏 ${ }^{1}$, 鷲山厚司 ${ }^{1}$, 二神幸次郎 ${ }^{1,2}$ \\ 福岡大学病院薬荗部 ${ }^{1}$, 福岡大学薬学部実務薬剤学 ${ }^{2}$
}

\section{Current Status and Problems Regarding Drug Administration via Feeding Tubes}

\author{
Hideto Minohara ${ }^{* 1}$, Shouichi Shiotsuka ${ }^{1}$, Takeshi Imamura ${ }^{1}$, Tadahiro Ikeuchi ${ }^{1}$, \\ Atsushi Washiyama ${ }^{1}$ and Koujiro Futagami, ${ }^{1,2}$ \\ Department of Pharmacy, Fukuoka University Hospital ${ }^{1}$, \\ Department of Pharmaceutical and Health Care Management, Faculty of Pharmaceutical Science, \\ Fukuoka University ${ }^{2}$ \\ $\left[\begin{array}{l}\text { Received October 13, } 2011 \\ \text { Accepted February 1, } 2012\end{array}\right]$
}

A simple suspension method was employed from December 2006 for drugs prescribed from 3 of 20 departments of Fukuoka University Hospital where tablets or capsules were often grinded. After two years, this method was employed in 11 departments. To investigate the current status and problems regarding the simple suspension method, a questionnaire survey was conducted involving all nurses working at this hospital. Responses were obtained from 681 nurses (94.1\%). The results showed that the drugs that should be suspended were not sufficiently disintegrated, and drugs were not sufficiently disintegrated when multiple drugs were suspended at the same time, suggesting the need for confirming the cause of insufficient disintegration at each time of drug administration. The results also showed that the conventional crushing method was preferred among nurses due to the simple procedure. We have found that these nurses do not fully understand the advantages of this method such as drug discrimination, discontinuation of drug administration, and prevention of tube clogging, suggesting the need for continuously providing drug information for nurses.

Key words — simple suspension method, feeding tubes, drug information, pharmacist, nurse

\section{緒言}

簡易懸濁法とは錠剂やカプセル剂を粉砕せずに 約 $55^{\circ} \mathrm{C}$ の温湯で懸濁させチューブから投与する方 法であり, 2001 年に倉田らにより報告された ${ }^{1 \sim 21}$. 簡易懸濁法は粉砕調剤時におこりうる光や吸湿に よる薬効の低減や薬剤のロスを回避できる.

福岡大学病院 (以下, 当院) は 26 診療科, 病 床数 915 床の特定機能病院である. 当院では看護 部と協議し, 全 20 病棟のうち処方せん粉砕指示 の多い救命救急センター, 神経内科・健康管理科 病棟，脳神経外科病棟で簡易懸濁法を 2006 年 12 月に開始した。 2 年 2 カ月後には 11 病棟まで拡
大することができた，そこで，簡易懸濁法実施現 場での現状と問題点を検討するため, 実際に経管 投与を行っている看護師にアンケート調查を実施 したので報告する.

\section{方法}

当院に勤務するすべての看護師（724 名）を対 象に 2009 年 2 月にアンケート調査（図 1)を行っ た．回収したデー夕の解析にあたり看護業務に対 し粉砕法を有用とする群 (粉砕法群) と簡易懸濁 法を有用とする群（簡易懸濁法群）に分け比較検 討を行った２ 群間の比較は unpaired $t$-test, Chi-

\footnotetext{
*福岡県福岡市城南区七隈7丁目45番1号
} 


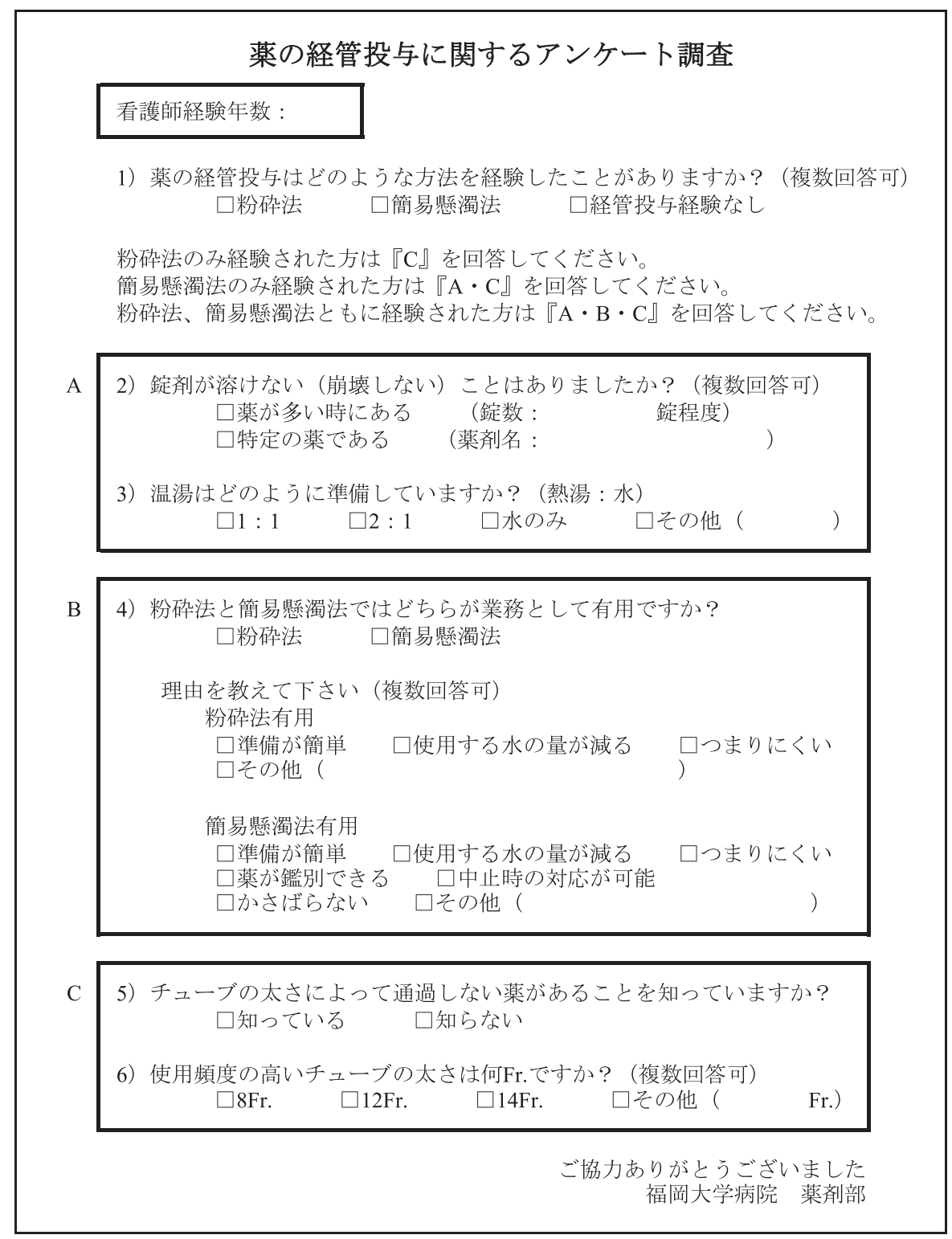

図 1 アンケート調査用紙

square testにより有意差検定を行った.

\section{結果}

681 名 $(94.1 \%)$ からアンケートの回答があり, その内訳を表 1 に示す。経管投与の経験がない 看護師は 98 名 $(14.4 \%)$ と少なく, 583 名 $(85.6 \%)$ の看護師がいずれかの方法で経管投与を経験して いた。

簡易懸濁法経験者 492 名のうち 157 名 (31.9\%) が錠数の増加による崩壊不良を経験していた。崩 壊不良時の錠数を 57 名が回答しており，その内 訳を図 2 (a) に示す。2 名 $(3.5 \%)$ は 1 錠であっ
表 1 アンケート回答者の内訳 $(n=681)$

\begin{tabular}{lc}
\hline \hline \multicolumn{1}{c}{ 内訳 } & 回答数 (回答率) \\
\hline 粉砕法および簡易懸濁法の & 420 名 $(61.7 \%)$ \\
両方法経験あり & 91 名 $(13.4 \%)$ \\
粉砕法のみ経験あり & 72 名 $(10.6 \%)$ \\
簡易懸濁法のみ経験あり & 98 名 $(14.4 \%)$ \\
経管投与の経験なし &
\end{tabular}

ても崩壊不良であると回答し，4 錠以上では 35 名（61.4\%）となった。一方，特定の薬剤による 崩壊不良の経験があるのは 216 名 (43.9\%) であつ た。このうち 78 名から薬剤名の回答が得られ， それらの薬剤について当院の簡易懸濁法可否リス 


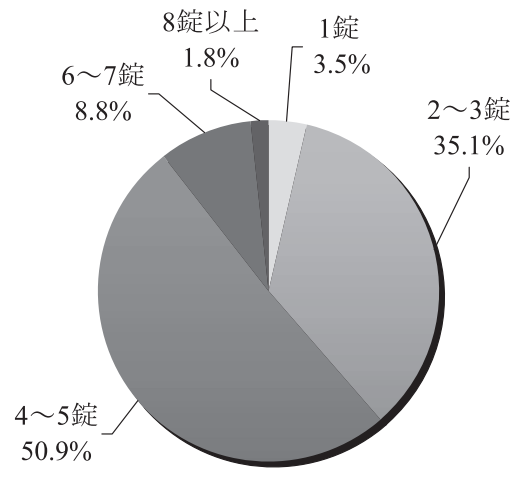

(a) 崩壊不良と回答された錠数 $(n=57)$

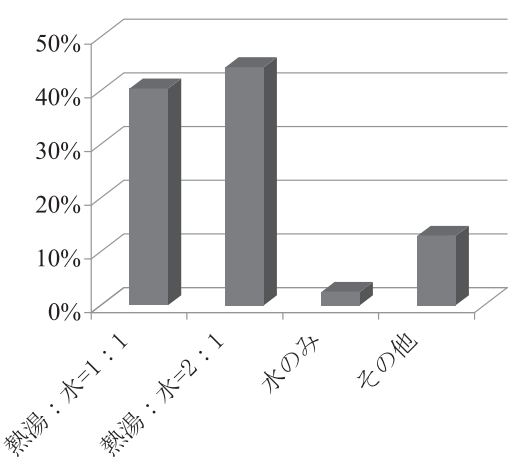

(b) 温湯の調製方法 $(\mathrm{n}=404)$

図 2 簡易懸濁法経験者を対象とした質問に対する回答

トを用いて調查した（表 2)。簡易懸濁法が可能 な薬剤は 21 品目あり，このうち崩壊に関する条 件のない薬剤は 10 品目であった。 また，不可は 7 品目, データなしは 4 品目であった. 最も多かっ たのはタケプロン ${ }^{\circledR} \mathrm{OD}$ 錠であり，粒が残るとの 回答がみられた。

簡易懸濁法における温湯の調製方法について回 答が得られた 404 名のうち, 179 名 $(44.3 \%)$ は我々 が指導した方法（熱湯：水=2：1）で行ってい たが，異なった方法で行っている看護師も多かっ た（図2（b））。薬剤通過に関する質問では 567 名より回答が得られ，チューブ径が小さいと通過 しない薬剤があることを知らないと回答したのは 306 名（54.0\%）であった。また，経管投与に使 用する頻度の高いチューブ径は 534 名より回答が 得られた. 複数回答に対しては解析上, 最小径を 抽出した。使用されている最小チューブ径は 12 フレンチ（Fr.）であるとの回答が最も多く 221 名（41.4\%）であった。また，85名（15.9\%）は 使用チューブ径がわからないと回答した。

看護業務に対する粉砕法と簡易懸濁法の有用性 については 404 名から回答が得られ，粉砕法が良 いと回答したのは 238 名 $(58.9 \%)$ であり，その 理由は準備が簡単というものが最も多く $84.9 \%$ で あった。一方, 簡易懸濁法は 116 名 $(41.1 \%)$ で, その理由も同様に準備が簡単という回答が最も多 く $65.1 \%$ であった。 また，鑑別が可能であること や中止時の対応が可能であることを理由とした看 護師はそれぞれ $25.3 \%, 21.1 \%$ であった。そこで，
表 2 簡易懸濁法により崩壊不良と回答された薬剤 (複数回答可) $(\mathrm{n}=78)$

\begin{tabular}{|c|c|c|}
\hline 薬剂名 & 回答人数 & $\begin{array}{l}\text { 可否データ } \\
\end{array}$ \\
\hline エルカルチン ${ }^{\circledR}$ 錠 & 12 & 可 (条件なし) \\
\hline フェロミア錠 & 10 & 可 (条件なし) \\
\hline エパデール $\mathrm{S}^{\circledast}$ & 3 & 可（条件なし） \\
\hline アスピリン「バイエル」® & 2 & 可 (条件なし) \\
\hline アテレック『錠 & 1 & 可（条件なし） \\
\hline エンテロノン ${ }^{\circledR} \mathrm{R}$ 散 & 1 & 可（条件なし） \\
\hline  & 1 & 可（条件なし） \\
\hline シンメトレル錠 & 1 & 可 (条件なし) \\
\hline 日本薬局方 ダイオウ末 & 1 & 可（条件なし） \\
\hline ムコス夕錠 & 1 & 可 (条件なし) \\
\hline パナルジン®錠 & 5 & 可（要破壊） \\
\hline ヒルナミン・錠 & 2 & 可（要破壊） \\
\hline ロキソニン®錠 & 2 & 可（要破壊） \\
\hline アリナミン ${ }^{\circledR} \mathrm{F}$ 糖衣錠 & 1 & 可（要破壊） \\
\hline トリプタノール錠 & 1 & 可（要破壊） \\
\hline タケプロン ${ }^{\circledR} \mathrm{OD}$ 錠 & 15 & 可 (顆粒残存) \\
\hline 重カマ「ヨシダ」 & 9 & 可 (顆粒残存) \\
\hline アローゼン ${ }^{\circledR}$ 顆粒 & 3 & 可 (顆粒残存) \\
\hline タナドーパツ顆粒 & 3 & 可 (顆粒残存) \\
\hline ベリチーム唒己合顆粒 & 2 & 可 (顆粒残存) \\
\hline リーバクト唒己合顆粒 & 1 & 可（顆粒残存） \\
\hline ガバペン 錠 & 7 & 不可 \\
\hline アダラート ${ }^{\circledR} \mathrm{CR}$ 錠 & 2 & 不可 \\
\hline アデホスコーワ顋粒 & 2 & 不可 \\
\hline バイアスピリン®錠 & 2 & 不可 \\
\hline ペンタサツ錠 & 2 & 不可 \\
\hline 硫酸ポリミキシン $\mathrm{B}^{\circledR}$ 錠 & 2 & 不可 \\
\hline オメプラール錠 & 1 & 不可 \\
\hline クレメジン細粒 & 3 & データなし \\
\hline デパケン ${ }^{\circledR}$ 細粒 & 1 & データなし \\
\hline ヘルラートミニ & 1 & データなし \\
\hline レナジェル四錠 & 1 & データなし \\
\hline
\end{tabular}

すべての質問項目に回答した 303 名を対象に粉砕 法群と簡易懸濁法群に分け比較検討を行った。表 3 に示すように粉砕法群では簡易懸濁法群と比べ 
表 3 粉砕法または簡易懸濁法を有用とする看護師の特徵

\begin{tabular}{|c|c|c|c|}
\hline 項目 & $\begin{array}{c}\text { 粉砕法群 } \\
\mathrm{n}=190\end{array}$ & $\begin{array}{c}\text { 簡易懸濁法群 } \\
\mathrm{n}=113\end{array}$ & $p$ 值 \\
\hline 経験年数（年） & $8.0 \pm 6.8$ & $7.6 \pm 6.8$ & $0.636^{\#}$ \\
\hline $\begin{array}{l}\text { 崩壊不良を経験（あり／なし） } \\
\text { 薬剂数が多い場合 } \\
\text { 特定の薬㓱 }\end{array}$ & $\begin{array}{c}69 / 121 \\
97 / 93\end{array}$ & $\begin{array}{l}48 / 65 \\
56 / 57\end{array}$ & $\begin{array}{l}0.287^{\dagger} \\
0.801^{\dagger}\end{array}$ \\
\hline $\begin{array}{l}\text { お湯の調製方法 } \\
\text { 問題あり/なし }\end{array}$ & $104 / 86$ & $56 / 57$ & $0.383^{\dagger}$ \\
\hline $\begin{array}{c}\text { チューブ径による薬剤通過 } \\
\text { 知らない／知っている }\end{array}$ & $90 / 100$ & $53 / 60$ & $0.937^{\dagger}$ \\
\hline 使用チューブの最小径（Fr.） & $10.6 \pm 2.9$ & $11.7 \pm 2.2$ & $<0.001^{\#}$ \\
\hline
\end{tabular}

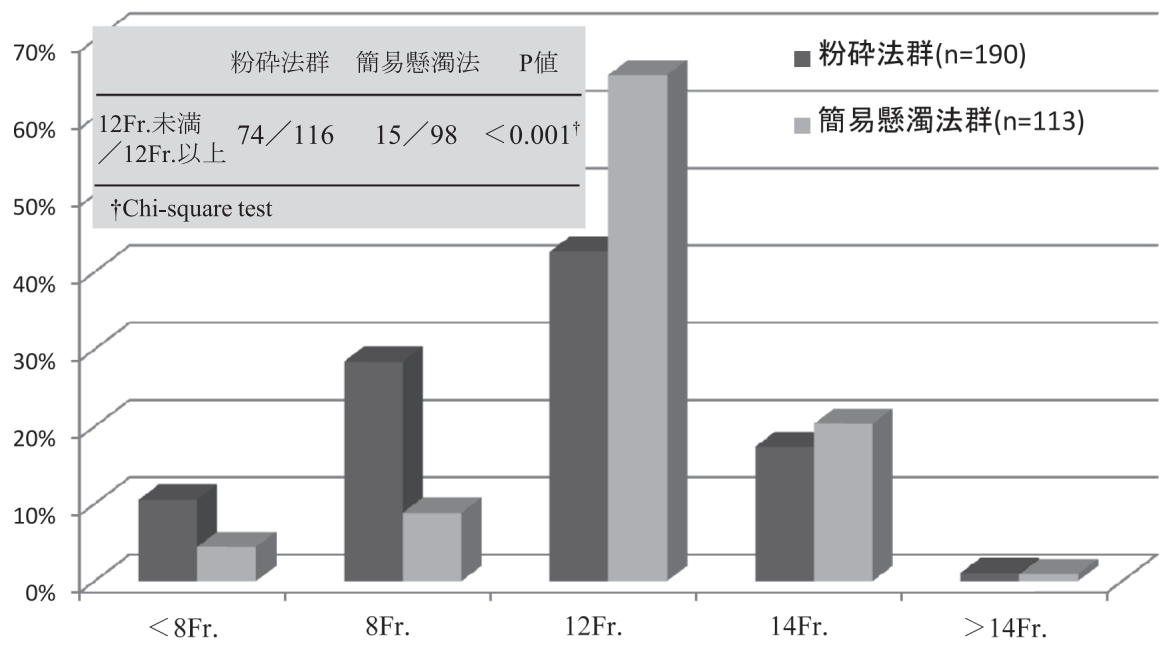

図 3 粉砕法群と簡易懸濁法群における使用チューブ最小径の比較

径の小さなチューブを使用しており有意な差を認 めた $(p<0.001)$ 。しかし，ほかの項目では 2 群 間に違いを認めなかった。また，使用チューブ径 が 12Fr. 未満の場合は粉砕法群が有意に多かった $(p<0.001)$ (図 3).

\section{考察}

崩壊不良であると回答のあった薬剤の中には, 簡易懸濁法不可やデー夕のない薬剤がみられた。 菅原らは処方オーダリングシステムに簡易懸濁法 可否デー夕を組み込むことで医師の処方時に適切 な薬剤選択を可能にし，簡易懸濁法導入の円滑化 やリスクマネジメントにおいて有用であると報告 している ${ }^{3)}$. 当院では本調查の結果より院内医薬 品集の本文中に簡易懸濁法の可否を追記したが,
処方オーダ時に簡易懸濁法可否がわかるシステム の導入を検討していく必要があると考えられる. また，製剤的特徵から顆粒が残存する薬剂が崩壊 しないとの回答も多かった．特に，タケプロン® $\mathrm{OD}$ 錠は腸溶性顆粒を含む製剂であり，顆粒の破 壊は薬効の低下をきたすと考えられる．従って， 顆粒が残存する薬剤についてはその旨を払い出し 時に情報提供する必要がある。ささらに, 崩壊に対 する条件のない簡易懸濁法可能薬郕が崩壊不良で あるとの回答もみられたが，その原因として，複 数の薬片を同時に崩壊懸濁させたことが考えられ る. $\mathrm{pH}$ の変化により遊離型となり溶解性が低下 し析出する薬剤や塩化ナトリウムとの同時懸濁に より崩壊不良となる薬剤が報告されており ${ }^{4)}$, 多 剂での同時懸濁時の情報提供が必要である。しか し，その組み合わせは無数に存在するため病棟担 
当薬片師や看護師と連携し，データを蓄積してい く必要があると考えられる.

温湯の調製は我々の指導とは異なった方法で 行っていた看護師が多かったが，アンケート後に 病棟では $100^{\circ} \mathrm{C}$ の熱湯が使用できなくなり給湯器 からの約 $60^{\circ} \mathrm{C}$ の温湯のみとなったため, この温 湯をそのまま使用する方法へ運用を改訂した。こ れにより温湯の調製に対する業務負担は軽減でき ると考えられる。また，指導と異なった調製はな くなるものと思われる。

調剤時 $12 \mathrm{Fr}$. 以上の径が必要である薬剤に対し ては注意喚起しているが，半数以上がチューブ径 によって通過しない薬剤があることを知らなかっ た．また，使用しているチューブ径を知らずに投 与している場合があることも確認された．推奨径 より小さな径のチューブを使用している場合，閉 塞のリスクが高くなるためチューブ径に対する理 解の向上が今後必要であると考えられる.

看護業務に対しては，手技が簡便である粉砕法 が好まれていた。簡易懸濁法群においても準備が 簡単という理由が最も多く, 鑑別が可能であるこ とや中止時の対応が可能であるといったリスクマ ネジメント，医療経済面のメリットに対する理解 がまだ十分に得られてはいないことがわかった. また， 2 群間の比較において粉砕法群では使用 チューブ径が有意に小さく，12Fr. 未満を使用し ている場合は粉砕法が好まれていた。しかし，簡 易懸濁法の導入によりチューブトラブルが減少す ることが報告されており ${ }^{5 \sim 6)}$, 賦形を必要とせず 嵩の小さな簡易懸濁法の方が径の小さなチューブ を使用している場合は特に有用であると考えられ る。これらのことから院内勉強会などを通じて簡
易懸濁法のメリットに対し理解を得る必要がある と考えられる.

本調査により当院における簡易懸濁法の様々な 問題点や看護師の理解が十分には得られていない ことがわかった。山本らは簡易懸濁法の適正な運 用には薬剤師による情報提供が有用であることを 報告しており 要であると考えられる。 それにより当院において も簡易懸濁法の拡大, より安全な経管投与が行え るものと考えられる.

\section{引用文献}

1）倉田なお 久, 小松千絵, 平藤 彰, 森 義明, 経管 投与可能な固形製剤の検討と一覧表の作成, 医 療薬学, 2001, 27, 461-472.

2）倉田なおみ, “内服薬経管投与ハンドブック”, 藤島 一郎監修, じほう, 東京, 2002, pp.2-343.

3）菅原拓也, 松田圭一郎, 大沼朋子, 矢吹むつみ, 二瓶祥子, 伊藤和香奈, 斎藤順, 有川真理, 笠原 由子, 荒井浩一, 鈴木啓之, 簡易懸濁法導入と電 子カルテおよび調剤支援システムへの対応, 日 本病院薬剂師会雑誌, 2008, 44, 1057-1060.

4）簡易懸濁法研究会, “簡易懸濁法Q\&A”, 倉田 なおみ監修, じほう, 東京, 2007, pp.2-167.

5) 渡邊めぐみ, 日比 聡, 中西敏博, 河合 優, 井口 光孝, 武内有城, 経管栄養におけるチューブ閉塞 軽減の試み, 日本病院薬剤師会雑誌, 2006, 42, 637-640.

6）豊岡宏子, 簡易懸濁法の導入による経管薬剤投 与, Brain Nursing, 2005, 21, 68-71.

7）山本吉章, 井上裕貴, 堀部千治, 三島信行, 簡易懸 濁法を円滑に運用する上での薬剤師の役割, 医 薬品情報学, 2011, 12, 117-122. 